\title{
Sea floor morphology and Plio-Quaternary sedimentary cover of the Mallorca Channel, Balearic Islands, western Mediterranean
}

\author{
J. Acosta ${ }^{\mathrm{a}, *}$, M. Canals ${ }^{\mathrm{b}}$, A. Carbó ${ }^{\mathrm{c}}$, A. Muñoz ${ }^{\mathrm{a}}, \mathrm{R}$. Urgeles ${ }^{\mathrm{b}}$, \\ A. Muñoz-Martín ${ }^{\mathrm{c}}$, E. Uchupi ${ }^{\mathrm{d}}$ \\ ${ }^{a}$ Instituto Español de Oceanografia, Corazón de María, 8, 28002 Madrid, Spain \\ ${ }^{\mathrm{b}}$ Departament d'Estratigrafia Paleontologia i Geociències Marines, GRC Geociències Marines, Universitat de Barcelona, \\ 08028 Barcelona, Spain \\ ${ }^{\mathrm{c}}$ Facultad de C.C. Geológicas, Universidad Complutense de Madrid, 28040 Madrid, Spain \\ ${ }^{\mathrm{d}}$ Woods Hole Oceanographic Institution, Woods Hole, MA 02543, USA
}

Received 7 November 2001; received in revised form 10 December 2003; accepted 12 February 2004

\begin{abstract}
A complete multibeam coverage of the sea floor of Mallorca Channel, in the western Mediterranean, was recorded during the Spanish Exclusive Economic Zone surveys in 1995, 1996 and 1997. These data, combined with previous high-resolution seismic reflection profiles, allow an assessment of the geomorphology of the area. The channel seafloor is disrupted by a fault complex and pockmarks. Motion along the faults split the sea floor into a series of undulations separated by narrow V-shaped notches. Faulting may be a consequence of recent seaward gravitational sliding that occurred along a soft surface at the top of a late Messinian-early Pliocene unit and a late Messinian evaporite. These units have been tilted during recent subsidence of the Mallorca Channel at the same time that the insular shelf was uplifted along a fault at the shelf's edge. The set of pockmarks in the channel sequence were probably formed by the expulsion of gas of hydrothermal origin, and expulsion may have been enhanced by the faulting. This gas seepage could be an additional factor leading to sediment instability.
\end{abstract}

Keywords: Balearic Islands; geohazards; landslides; raft tectonics; pockmarks

\section{Introduction}

The Balearic Promontory is the most important elevation of the western Mediterranean basin, west of the Corsica-Sardinia Block, (Fig. 1). The Promontory, a northeast prolongation of the Betic system of southern Spain, is $350 \mathrm{~km}$ long, $105 \mathrm{~km}$ wide and $1000-2000 \mathrm{~m}$ high with respect to the surrounding basins (North and South Balearic basins). It was formed by a combination of pre-Oligocene subduction of Africa beneath Eurasia, rifting and sea floor spreading (Acosta et al., 2001a). The Balearic Promontory is made of three main blocks separated by seaways. Ibiza Channel separates the Promontory from the Iberian margin to the west, the Mallorca Channel separates the islands of Ibiza/Formentera from Mallorca/Cabrera, and the Menorca Channel separates Mallorca from Menorca at the northeast end of the Promontory (Fig. 1). In a previous paper we described the distribution of post-Messinian vol- 


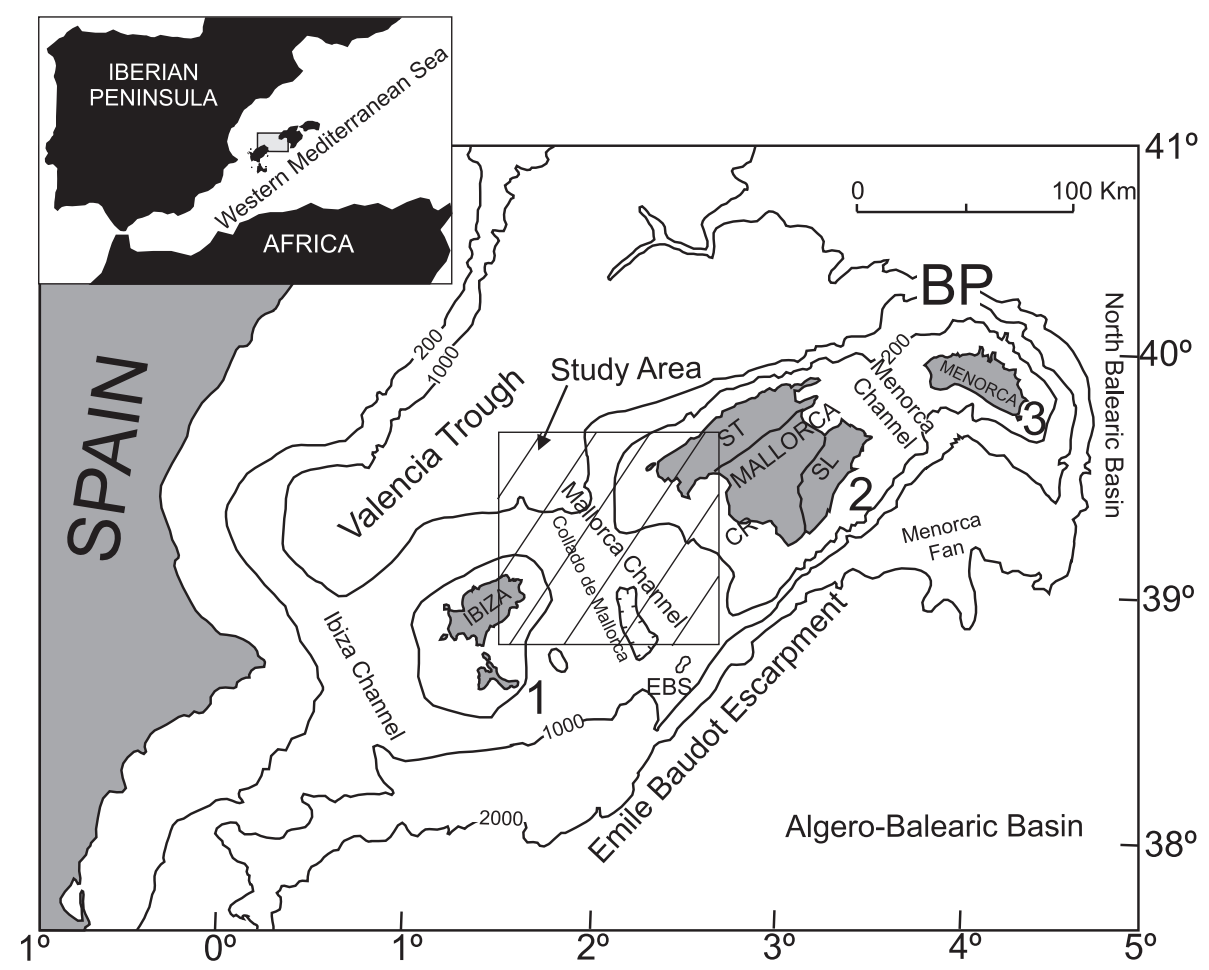

Fig. 1. Bathymetric map of the Balearic Promontory showing the location of the study area. Contours in meters. BP: Balearic Promontory; CR: Central Rift; EBS: Emile Baudot Seamount; SL: Llevant Range; ST: Tramuntana Range. 1: Ibiza Block; 2: Mallorca Block; 3: Menorca Block.

canic pinnacles on the Promontory and the tectonic history of the Emile Baudot Escarpment (Fig. 1), a possible transform fault along the southeast side of the Balearic Promontory (Acosta et al., 2001a). In a second paper we discussed the origin of small pockmarks in the Ibiza Channel that we inferred were formed by the expulsion of gas along faults (Acosta et al., 2001b). In this manuscript we describe the shallow structure and surface processes on the Mallorca Channel. This study provides the basis for an assessment of possible geologic hazards in the region.

\section{Methods}

Two data sets were used in this study. One set consists of multibeam data collected during the Spanish Exclusive Economic Zone Program surveys (Muñoz et al., 1998a,b; Pardo de Domlebum et al., 1998; IEO-IHM, 1999a,b). The data were collected using the Simrad EM-12S and EM-1000 systems with the multibeam tracks positioned as to insonify $100 \%$ of the areas with a $33 \%$ overlap between data corridors. Navigation during the surveys was via a double GPS-D system with satellite corrections from the Skyfix and Omnistar systems using a Konmap navigation software package. This provided a position accuracy of $\pm 10 \mathrm{~m}$. Survey speeds, depending on sea-state, averaged 8-11 knots. This resulted in a variable swath width from 3.5 to 7 times the water depth, depending on the system and configuration used. Water velocity corrections were made using XBT/XSV Sippican expendable probes (1 or 2 per day) that provided pressure-temperature or direct vertical sound velocity profiles which were introduced in real time into the logging software package (Simrad Mermaid). Bathymetric data were processed using Neptune and Roxar's Cfloor software for editing and grid generation, and IberGIS for DTM and morphometric treatment. The second data set consists of high resolution seismic reflection profiles obtained by the Marine Geology Group of the University of 
Barcelona in 1991 using two sound sources, a 500-J Uniboom with a pulse length of $9 \mathrm{~ms}$, and a 3600-J Sparker with a pulse length of $12 \mathrm{~ms}$. The analog data were recorded on an EPC graphic recorder. Navigation during the geophysical survey was by means of a Loran $\mathrm{C}$ system with an estimated precision of $\pm 25 \mathrm{~m}$.

\section{Seafloor morphology}

At the northwestern end of the Mallorca Channel is a depression (NWD in Fig. 2) deepening northward towards the Valencia Trough. At its southeastern end of the channel is a second, almost elliptical depression, about $1000 \mathrm{~m}$ deep low (SED in Fig. 2) bounded at its southeast side by a northeast-southwest trending high along whose crest is the flat-topped Emile Baudot Seamount (EBS in Fig. 1). Connecting these two lows is a narrow north trending channel, $3 \mathrm{~km}$ wide and with a sill depth of $740 \mathrm{~m}$, the Mallorca Collado (MC in Fig. 2). A blowup of a segment of the Mallorca Channel off Andraitx, Mallorca (Fig. 3) shows that the sea floor of the northern embayment is undulating and that it is entrenched by a several kilometer wide trough originating in the Mallorca insular slope (T, Fig. 3). Along the axis of this low is a linear $20 \mathrm{~m}$ high ridge $(\mathrm{H}$, Fig. 3). The most prominent feature in the area is the Morrot de $\mathrm{Sa}$ Dragonera, a $>460 \mathrm{~m}$ high, $9 \times 5 \mathrm{~km}$ circular seamount, north of Ibiza, which base lies at a depth of 1400 m (Canals et al., 1982; Figs. 2 and 3).

The upper insular slope off Mallorca displays two distinct morphologies (MUS. Fig. 2). Whereas the east-west trending segment is smooth, the northsouth aligned section is cut by gullies and a retrogressive slide showing four scars. These two slope sections are separated by a southwest trending high, the Andraitx Salient, which is tilted to the southeast (AS, Fig. 2). The northwest side of this high is smooth whereas its southeast side is irregular.

The Ibiza insular upper slope is characterized by a north-northeast trending high (IUS, Fig. 2). Mallorca Collado, the passage connecting the northwestern and the southeastern depressions, is located between the Andraitx Salient and the high north-northeast of

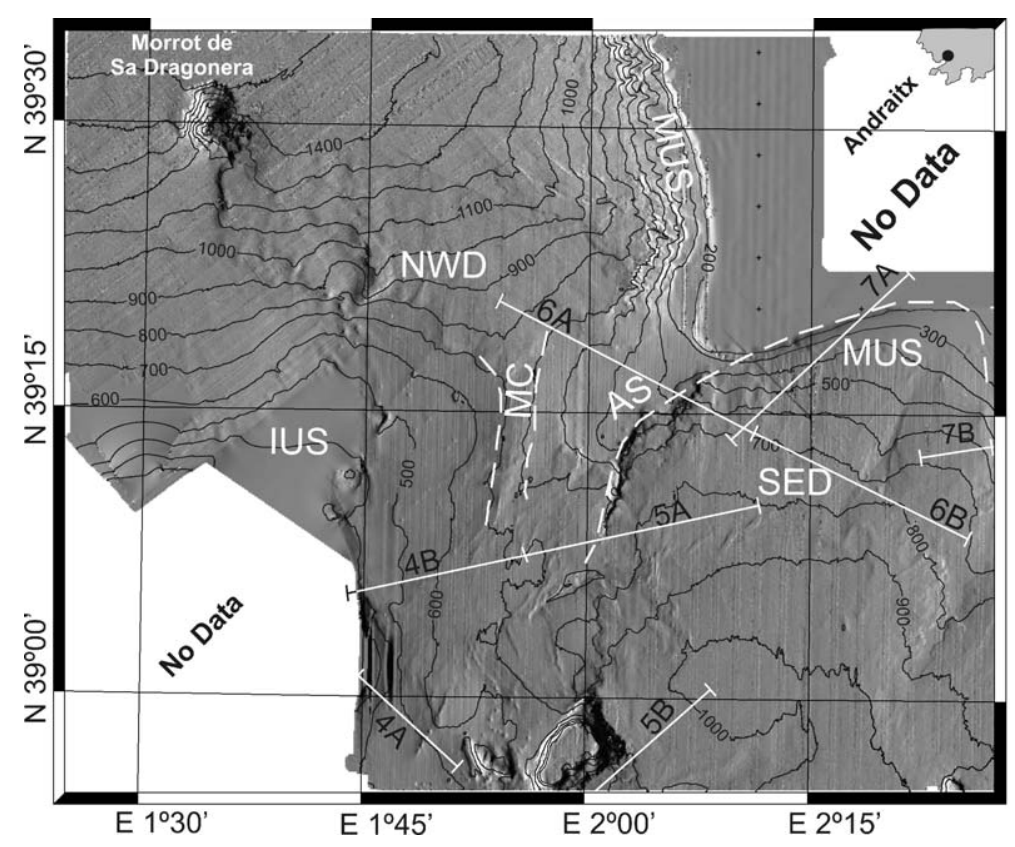

Fig. 2. Bathymetry map of a segment of the Mallorca Channel. Contours in meters are superimposed on a shaded relief map of the region. Light is from the northwest. MC: Collado de Mallorca; NWD: northwestern depression; SED: southeastern depression; MUS: Mallorca upper slope; IUS: Ibiza upper slope; AS: Andratx Salient. 


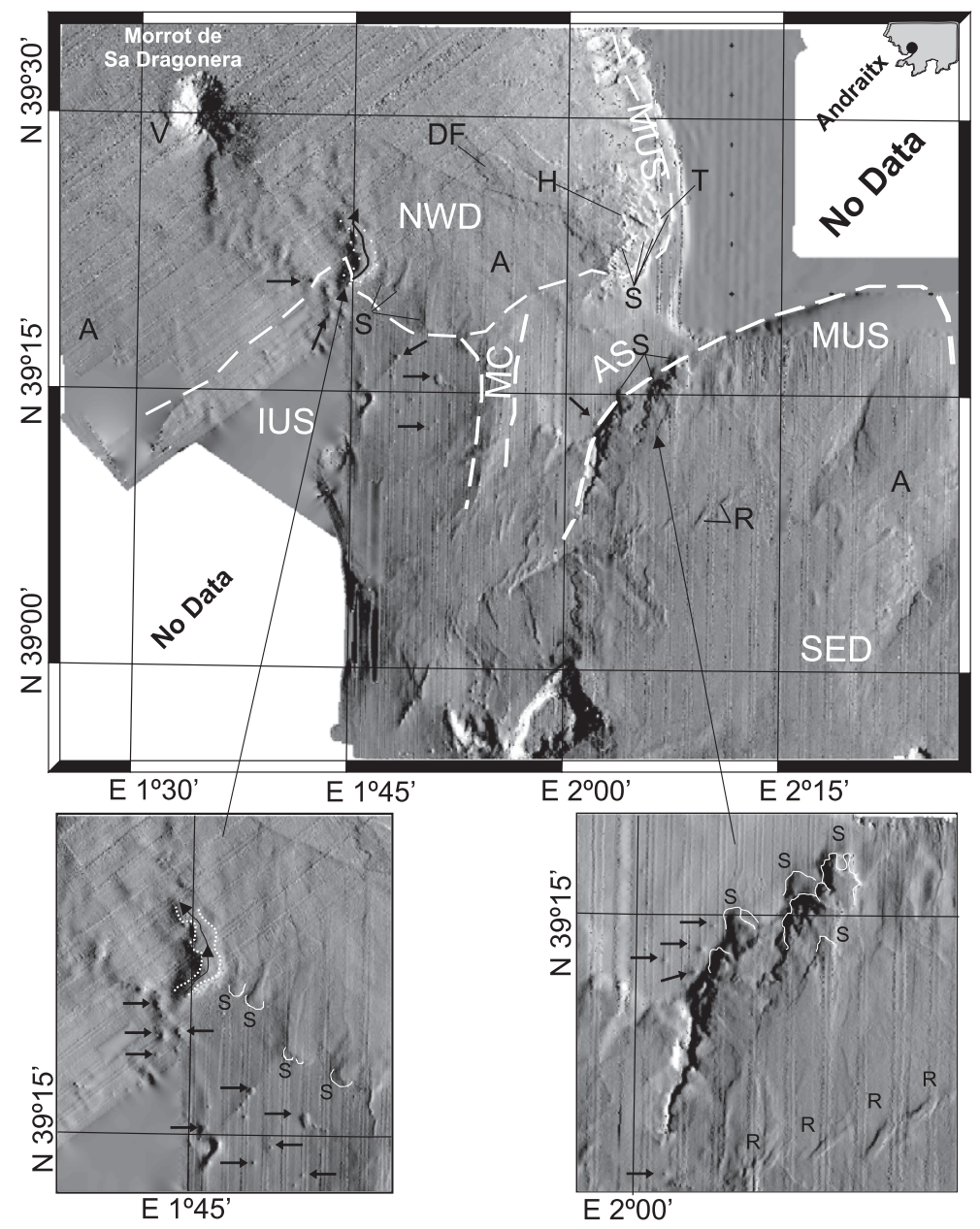

Fig. 3. Shaded relief image of the Mallorca Channel area compiled from multi-beam data. A: Navigation artifact; arrows: pockmarks; R: rectangular depressions; DF: debris flow deposit; S: slide scar; V: volcanic seamount.

Ibiza. Swath data indicate an essentially smooth sea floor on the northwestern depression. In contrast, more irregular contours suggest that micro-relief features disrupt the sea floor of the southeastern depression (Figs. 2 and 3).

The interpretative shaded relief image allows us to infer the processes that shaped the sea floor of the Mallorca Channel (Fig. 3). The morphology results from a combination of slides, fluid venting and pockmark formation, and volcanic outcrops cutting the Plio-Quaternary sedimentary sequence. Indications of slope retrogression also has been observed on the scars cutting the Mallorca insular upper slope (S, Fig. 3). Tiny slides are visible north of the north- northeast high off Ibiza and south of the Andraitx Salient at depths in excess of $600 \mathrm{~m}$ (Fig. 3, blowup section). Debris flow lobes also are developed downslope of some of the upper slope scars, particularly on the Mallorca insular slope north of the Mallorca Collado (DF, Fig. 3). The main sea floor topographic irregularities at the southern edge of the Andraitx Salient also are the result of gravitational processes. The large gully on the Ibiza northern slope (Fig. 3), southeast of Morrot de Sa Dragonera Seamount, widens close to a north-south alignment of pockmarks, thus suggesting a relation between the two features. This gully is bounded to the west by a buried high that is part of south-north alignment off northern 
Ibiza. These buried highs and the pockmarks described above are distributed along the same trend indicating a genetic relationship. The large, $700 \mathrm{~m}$ high Morrot Sa Dragonera Seamount could be related to the Cabrera volcanic field southeast of the study area (Acosta et al., 2001a). The nearly buried highs on the Ibiza insular slope also may have the same origin or may represent local sea floor exposures of Messinian sediments. Four small steep-sided rectangular depressions are observed between 800 and $900 \mathrm{~m}$ depth on the slope southeast of the Andraitx salient (R, Fig. 3). The origin of these depressions oriented roughly perpendicular to the isobaths is unknown.

\section{Seismic stratigraphy}

The high resolution seismic reflection profiles across the Mallorca Channel show a section that we infer to represent the Messinian to Holocene succession that is characteristic of most of the northwestern Mediterranean (Figs. 4-7). At the base of the succession is a strong uneven reflector displaying noticeable relief. As observed on most profiles, this reflector truncates an underlying stratified sequence. We correlate this unconformity with Horizon $\mathrm{M}$, which was generated during the Messinian dessication of the Mediterranean (Montadert et al., 1978).

The U- to V-shaped features on Horizon M underneath the outer insular shelf and uppermost insular slope can be interpreted as erosive features sculptured during the dessication (Fig. 7, profile B). Thus we infer that Horizon $\mathrm{M}$ is the top of a network of fluvial valleys. A thin, partly stratified unit limited to lows on M may be correlative with the Messinian Upper Evaporites. Two structurally controlled highs on the southwest end of profile B (Fig. 5) might correspond to diapirs that may have originated from this unit. However, this unit appears to be too thin to be the origin of the structures leading us to propose that the source of the structures is the water saturated mud above the evaporites (see below).

Above Horizon $\mathrm{M}$ are two acoustic units, an acoustic transparent lower unit and a stratified upper one. We assume that the lower acoustic transparent unit resting on $\mathrm{M}$ represents the latest Messinian/postMessinian flooding of the Mediterranean. We date this unit as latest Miocene or earliest Pliocene age on the assumption by Riding et al. (1998) that the salinity crisis in the Mediterranean ended 5.5 Ma ago rather than in the early Pliocene.

From its acoustic signature we infer that the unit is a fine-grained deposit and its homogeneity also suggests that the unit was deposited rapidly. Such interpretation is supported by the investigation of Stanley (1985) who reported that fine-grained sediments formed the bulk of the unconsolidated Plio-Quaternary in the Mediterranean margins and basins. Apparently these sediments are of gravity-driven origin (slumps, slides, turbidites), hemipelagic deposition making up $30 \%$ of the sediments (sapropels) and a sequence of a combination of gravity flow and suspension origin. This and others studies have demonstrated that the Plio-Quaternary sediments in the Mediterranean are rich in sapropels (organic-carbonrich sediments; Cramp and O'Sullivan, 1999). It is these sediments that are the source of cold hydrocarbon seeps in the eastern Mediterranean (Coleman and Ballard, 2001) and similar sediments also are responsible for the mud volcanoes and mud diapirs in the Mediterranean Ridge (Limonov et al., 1996).

Thus, we propose the possibility that the diapirs on profile 5B (Fig. 5) may have originated from this unit rather than the Upper Evaporites suggesting that mobility of the sediments may be due to their fluid saturation state and the presence of gas with the faulting in the sediments providing pathways for this plastic material to migrate upwards (a plastic material is defined in the Glossary of Geology of the American Geological Institute is one in which strain produces continuous deformation without rupture material). Unfortunately such an interpretation has not been verified by sampling although the presence of pockmarks in the region (Acosta et al., 2001b) does support the possibility that the muds may be saturated with gas.

Cores recovered from the Balearic Promontory (Maldonado and Canals, 1982; Alonso et al., 1988; Canals and Serra, 1989) are too short and only sampled the upper meters of the upper stratified unit and the DSDP and ODP sites (DSDP sites 122, 123, 124 and 134: Ryan et al., 1973; DSDP sites 371 and 372: Hsü et al., 1977; ODP site 975: Comas et al., 1996) in the region are located off the Balearic Promontory and do not provide any information regarding the post Messi- 
A

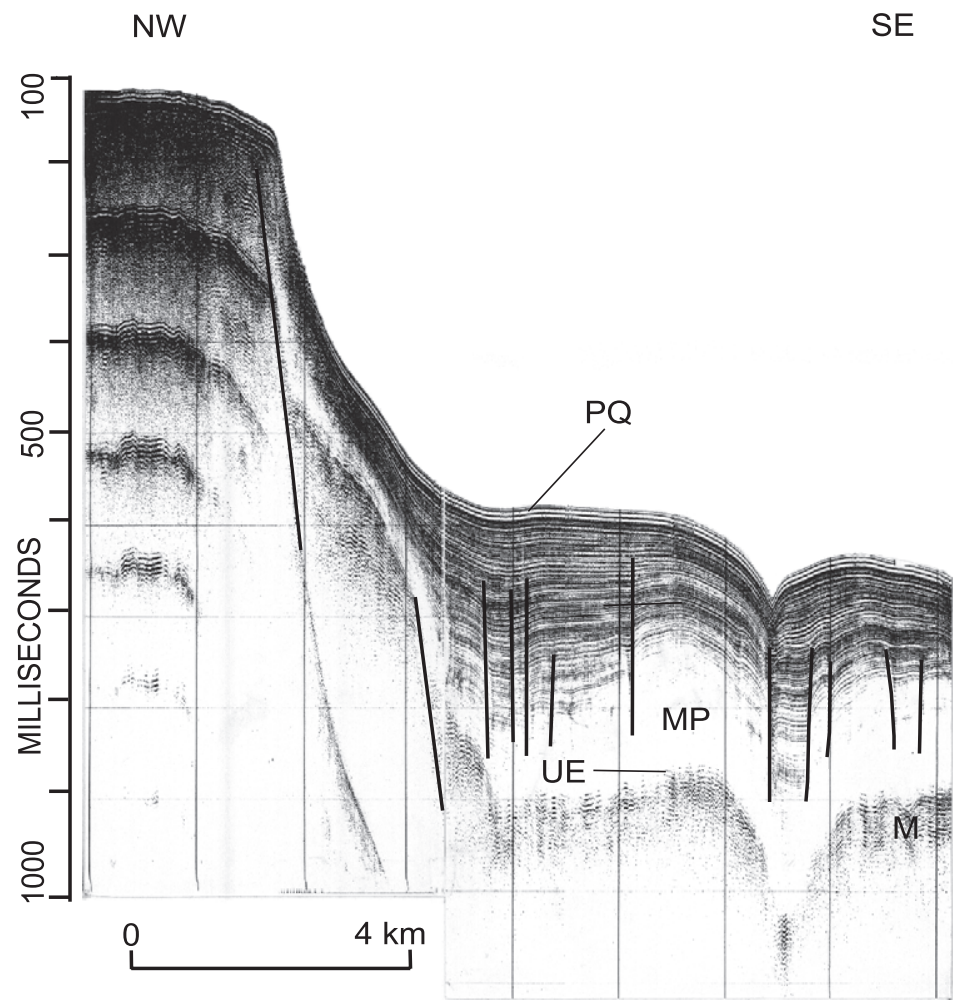

B

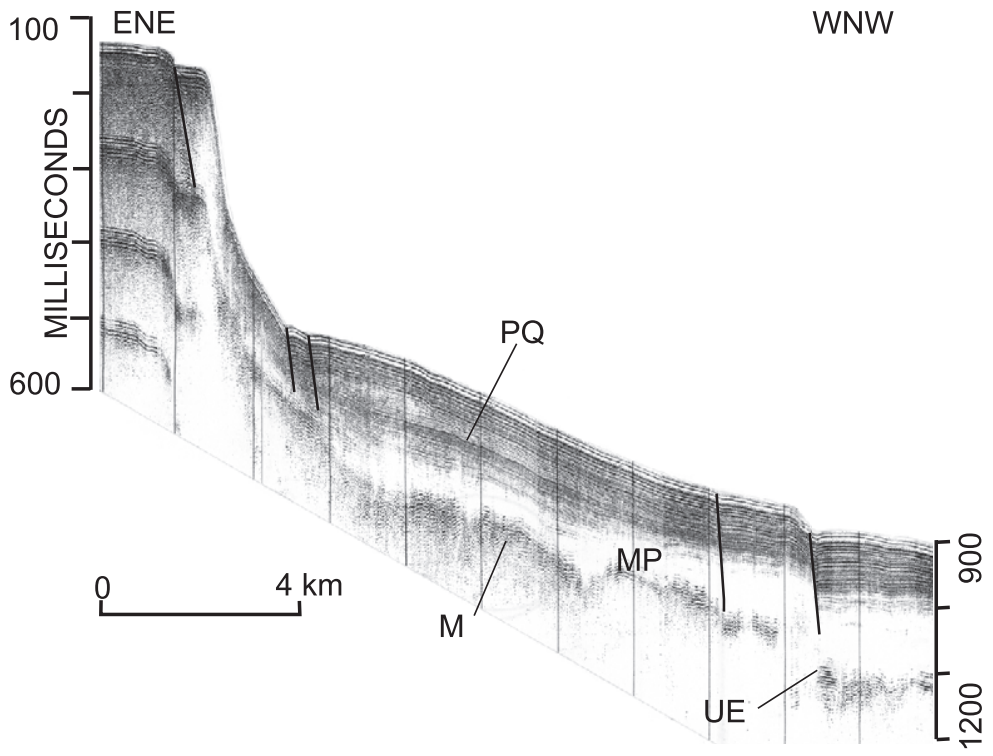

Fig. 4. Seismic reflection profiles (A and B) from the Mallorca Channel. See location in Fig. 2. M: Messinian unconformity; MP: Messinianearly Pliocene sediments; PQ: Plio-Quaternary sediments; UE: Messinian Upper evaporites. 


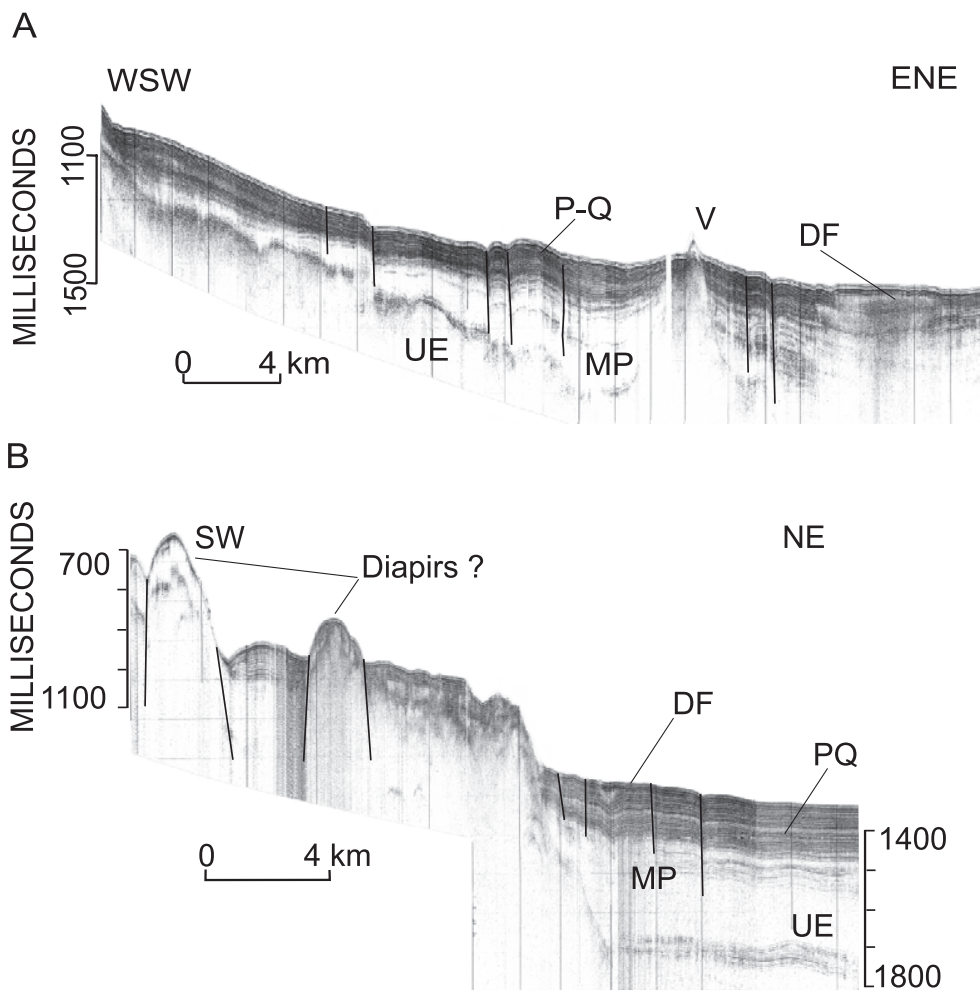

Fig. 5. Seismic reflection profiles (A and B) from Mallorca Channel. See location in Fig. 2. DF: debris flow deposit; MP: Messinian-early Pliocene sediments; PQ: Plio-Quaternary sediments; UE: Messinian Upper evaporites; V: volcanic pinnacle.

nian stratigraphy and lithology in the Promontory itself.

The seismic sections recorded during and prior to the DSDP and ODP cruises south and east of the Promontory do show an acoustic transparent unit resting on Miocene evaporites capped by a wellstratified upper unit. This sequence resembles the acoustic stratigraphy of the seismic reflection profiles from the Balearic Promontory described in this report. Those recorded in the Valencia Trough are somewhat different imaging a lower poorly stratified acoustic lower unit capped by a well-stratified upper unit. Although the seismic reflection profiles off and on the Promontory do display a similar acoustic signature it does not mean that they have similar lithologies.

Sites 124, 134, 371, 372 and 975 off the Promontory penetrated several hundred meters of Plio-Quaternary nanno or calcareous silty clay and ooze indicating that the deeper water sequences are dominated by biogenic hemipelagic components. DSDP sites 122 and 123 in a deep-sea channel system in the Valencia Trough sampled a Plio-Quaternary section that consisted of about 160-269 m of lower Pliocene graded sands silt, marl and oozes (turbidites and contourites) and Quaternary-upper Pliocene marl, oozes and graded sand (turbidites).

The well-stratified sequence resting on the transparent unit in the Balearic Promontory we infer to represent a Plio-Quaternary turbidite sequence. Such an interpretation is not unrealistic as core samples from the area indicate that at least the top of this unit consists of carbonate-rich sediments ranging from spillover sands to coarse to fine grained turbidites on the slope, to hemipelagic muds on deeper areas (Maldonado and Canals, 1982; Alonso et al., 1988; Canals and Serra, 1989; Maldonado and Nelson, 1990). The contact between the acoustic transparent and stratified units along the seismic reflection profiles ranges from sharp to gradual (Fig. 6). Transparent lenses within the stratified unit may represent buried 
A

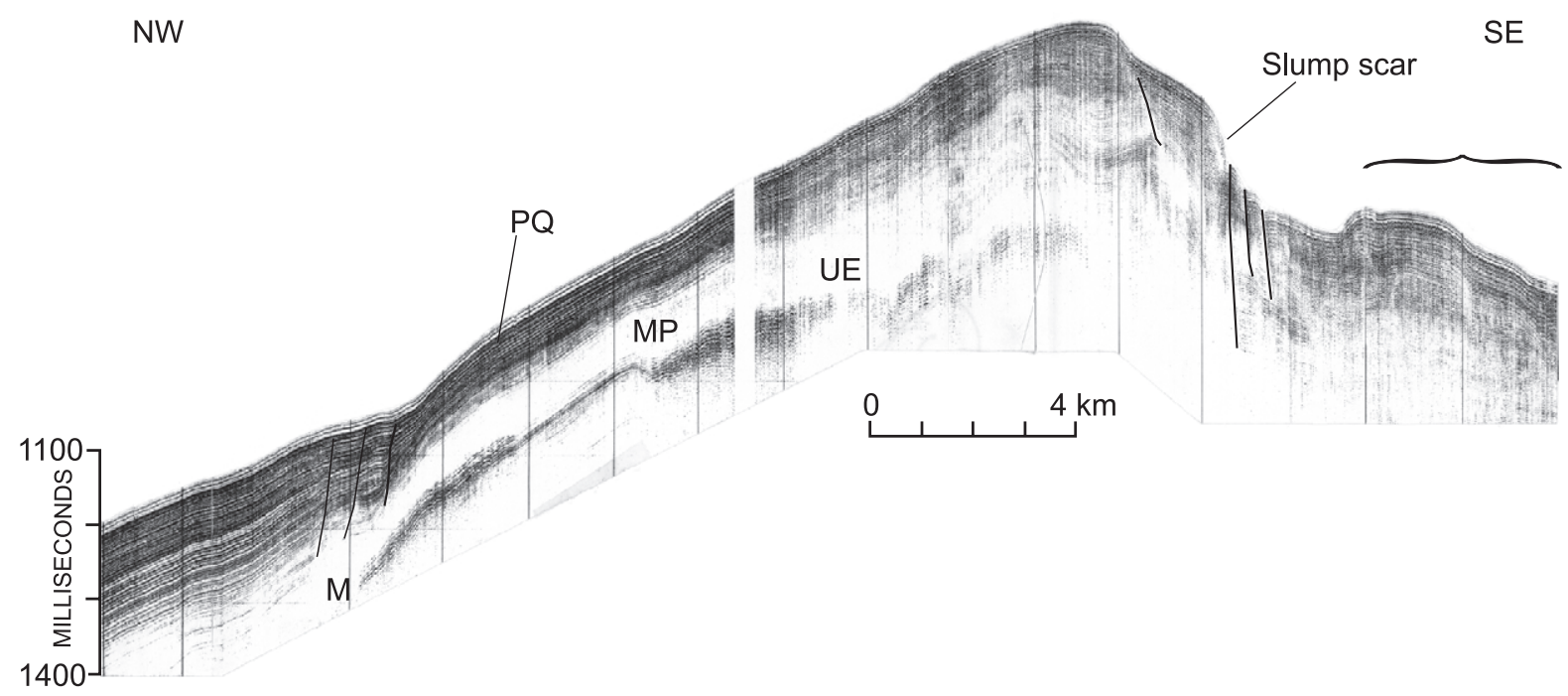

B

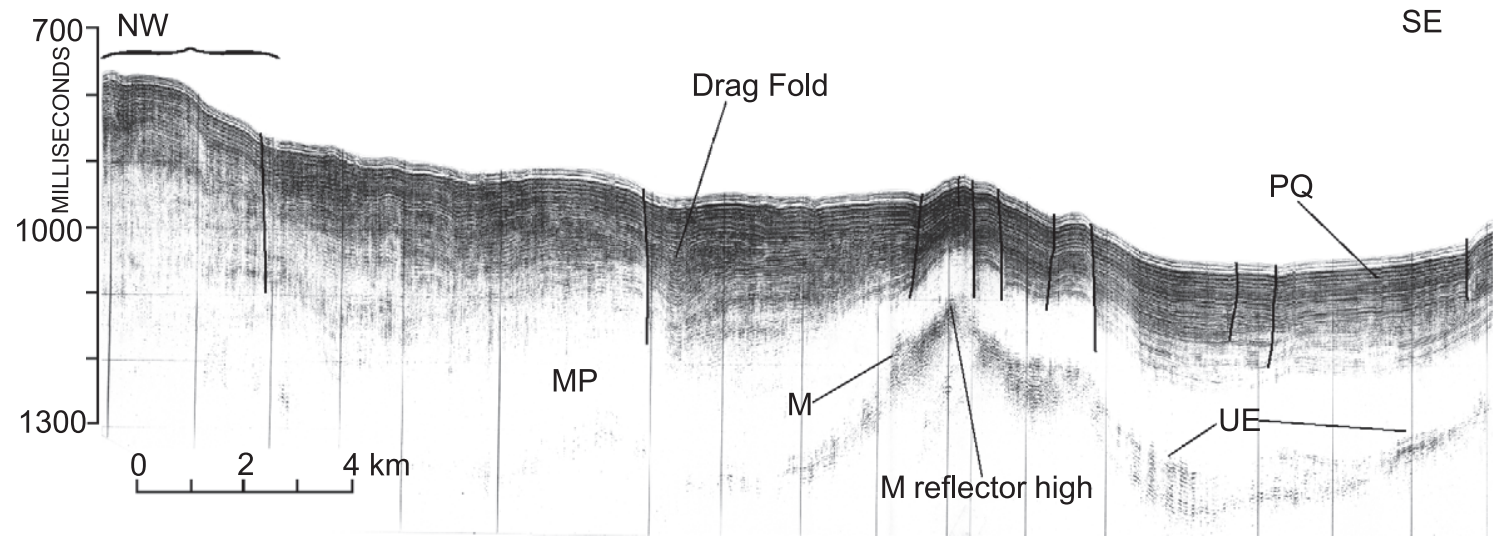

Fig. 6. Seismic reflection profiles (A and B) from the Mallorca Channel. See location in Fig. 2. M: Messinian unconformity; MP: Messinianearly Pliocene sediments; UE: Messinian Upper evaporites; PQ: Plio-Quaternary sediments.

debris flow deposits that extend several $\mathrm{km}$ downslope and are comparable to those reported by Ballesteros (2000) from the insular slope south of Mallorca.

The Plio-Quaternary sequence is disrupted by an extensive fault network that is imaged on most seismic reflection profiles. Fault disruption of the sea floor results in a wavy morphology indicating recent activity along these structures. These faults can be classified as capable faults, namely those that exhibit movement at or near the ground surface at least during the last 350,000 years, or show motion during the last
500,000 years, or have been active during the Quaternary (Panizza, 1996).

Fault-related down slope sediment displacement of the uppermost Plio-Quaternary sequence generated an undulating surface (profile A, Fig. 7) to slumps with prominent scarps on their landward sides. As a result of this down slope motion, the upper stratified sequence displays a noticeable increase in thickness down dip (Figs. 5 and 6A). The intersection of some faults with the sea floor also has produced V-shaped notches (Figs. 4A, 5A and 6B). These notches are 


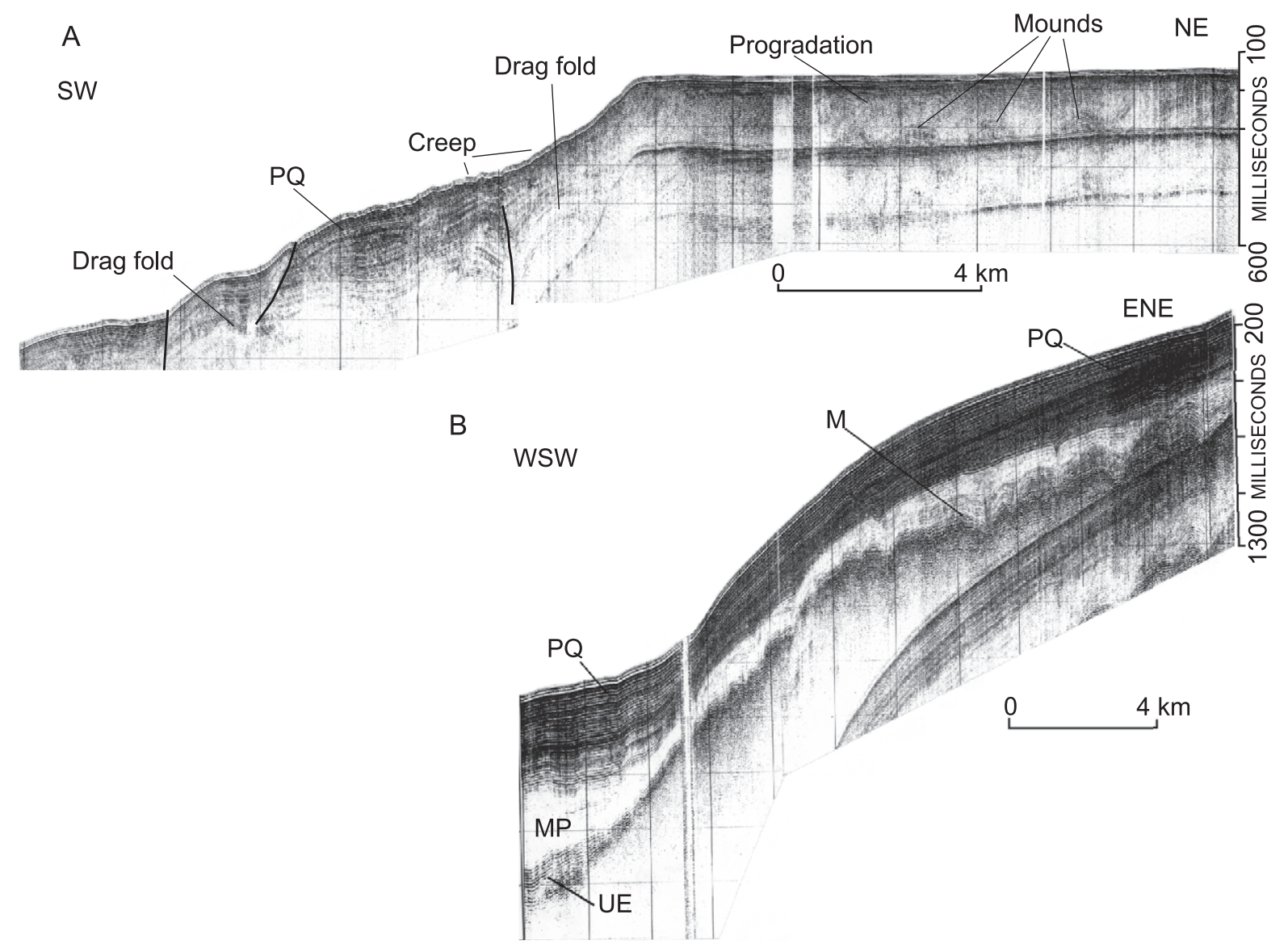

Fig. 7. Seismic reflection profiles (A and B) from the Mallorca Channel. See location in Fig. 2. M: Messinian unconformity; MP: Messinianearly Pliocene sediments; UE: Messinian Upper evaporites; PQ: Plio-Quaternary sediments.

narrow elongated depressions roughly parallel to the isobaths that correspond to the propagation of the fault planes on the sea floor. At places where the sea floor is affected by closely spaced fault planes it has led to the creation of a series of steps descending down slope. Motion along the faults also has resulted in the formation of drag folds (Fig. 6B).

Topographic irregularities on Horizon $\mathrm{M}$ on the slope, suggest that some of the faults may extend to this horizon. Such was the conclusion proposed by Acosta et al. (2001a), but our profiles cannot discern them. Only on those profiles crossing the insular shelf edge and upper insular slope (Figs. 4 and 7) suggest that faulting appears to be deep-seated. It is along these structures along the slope that the insular shelves were uplifted and the sediments seaward of the insular slope subsided leading to the basinward sliding of the surficial slope sediments along a décollement surface/ or surfaces, i.e. the top of the acoustic transparent unit and/or the Upper Evaporites. The transparent unit appears to have injected along the fault planes of the stratified unit as it slid basinward (Fig. 6). If this has taken place it reinforces our interpretation that the transparent unit as a soft mud. That the faults are not deep-seated appears to be supported by a multichannel seismic reflection profile recorded in the region (Vidal et al., 1998).

The multi-channel seismic ESCI-Valencia Trough profile, extending from Spain's eastern continental margin, across the Valencia Trough and the Balearic Promontory, to the oceanic basin south of the Promontory, show limited evidence of faulting on the high. 
As interpreted by Vidal et al. (1998), the profile only images three faults, one on the northwest side of the Mallorca Channel and two within the channel itself. The one on the northwest side extends deep into the section, another displaces Horizon M and the third occurs beneath $\mathrm{M}$. Yet the same profile was interpreted by Sabat et al. (1995) as showing extensive faulting beyond the shelf's edge from Horizon M to the Mesozoic cover above basement.

According to Sabat et al. (1995) the sediments above $\mathrm{M}$ are undisturbed with the faulting being roofed by M. Possibly the faulting does extend above $\mathrm{M}$ and is not imaged by the multi-channel profile because it lacks the resolution of the single channel seismic reflection profiles described in this report. If the faults imaged by Sabat et al. (1995) do extend above $\mathrm{M}$, then the faulting displayed by our profiles in the channel may be deep-seated. Although the scale of the multi-channel seismic profile included in Sabat et al. (1995) is too small for us to check their line interpretation, we tend to question the supposition that the faults extend above Horizon M.
We propose that the faulting above $\mathrm{M}$ in the channel lacks deep roots (thin-skined tectonics), and is due to gravitational processes associated with uplift of the insular shelf along some deep-seated fault system on the slope and subsidence of the region seaward of the slope. As discussed below such an interpretation is supported by the paucity of seismic activity in the region. It should be pointed out, however, that Olivera et al. (1992), who investigated the seismicity of the region since 1907 , inferred that the absence of seismicity in the Balearic Promontory might be due to the lack of observation.

Fig. 8A and B displays the depth below sea level of the Messinian unconformity (Horizon M) and the thickness of latest Messinian to Holocene sediments above the unconformity, respectively. The Messinian unconformity is less than $800 \mathrm{~ms}$ deep at the Mallorca Collado from where it further shallows towards Ibiza and Mallorca (Fig. 1). The minimum depth mapped is less than $400 \mathrm{~ms}$ to the north-northeast of Ibiza. We infer that reflector $\mathrm{M}$ is shallower under the modern shelves of Ibiza and Mallorca. From Mallorca Col-

A

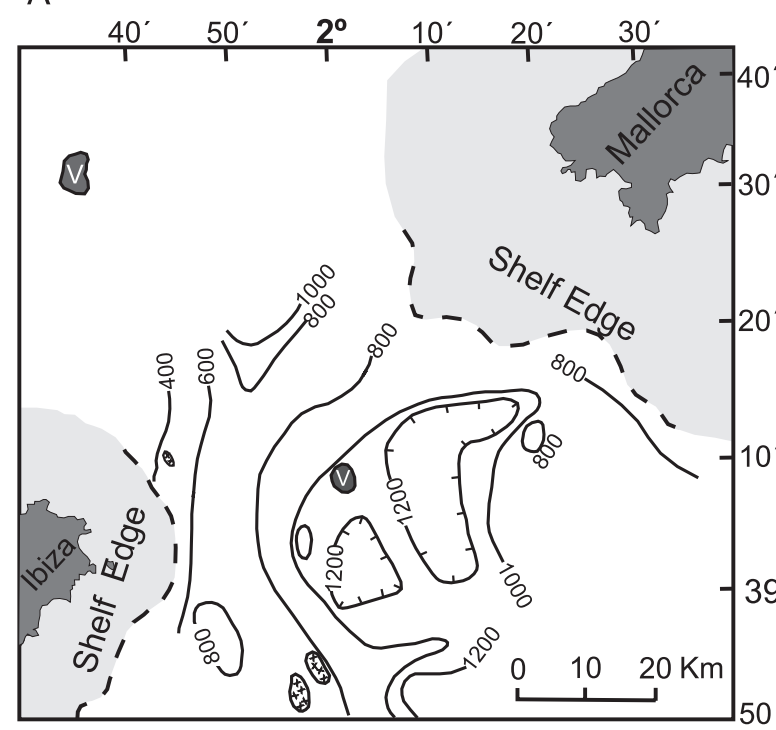

B

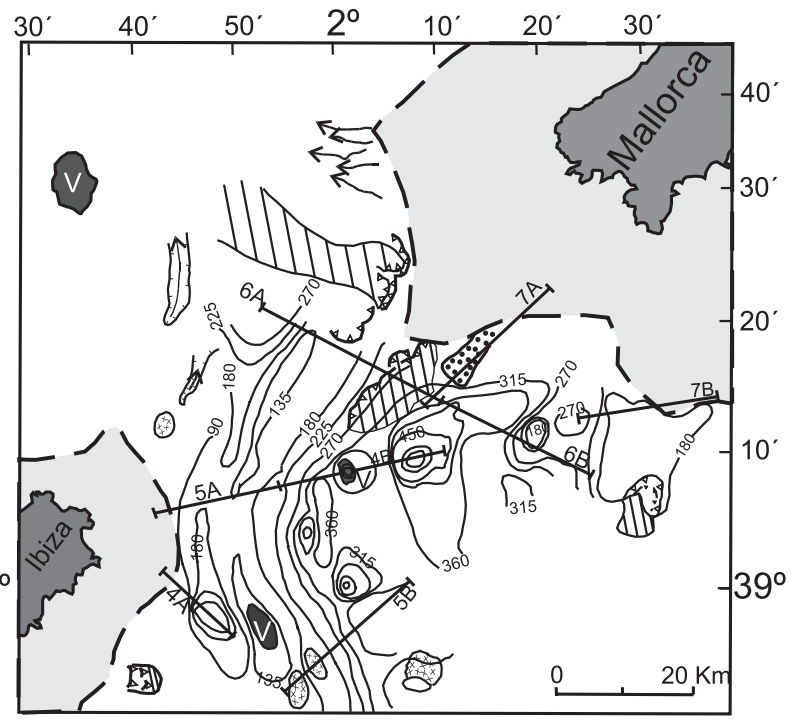

Fig. 8. (A) Time depth contour map of reflector on $\mathrm{M}$ in milliseconds below sea level. Both maps were constructed from a grid of highresolution seismic reflection profiles some of which are shown in Figs. 4-7 (B) Time thickness contour map of sediments above reflector M. Map was compiled from profiles in Figs. 4-7. V: volcanics seamounts; X pattern: diapiric structures; lines with arrows: gullies axes; lines with white triangles: slide scars; black dotted pattern: sediment creeping; lines pattern: extent of landsliding processes. Location of the seismic profiles in Figs. $4-7$ is also indicated. 
lado, Horizon $\mathrm{M}$ descends northwestwards and southeastwards to time depths in excess of $1000 \mathrm{~ms}$ (Fig. $8 \mathrm{~A})$. Horizon $\mathrm{M}$ reaches its maximum depth $(>1200$ $\mathrm{ms}$ ) in the depression east of Ibiza (Southeastern Depression, Fig. 2). A prominent high on the $M$ surface at the eastern side of this large depression rises locally to time depths of less than $800 \mathrm{~ms}$ (Figs. $6 \mathrm{~B}$ and $8 \mathrm{~A}$ ). Overall, the depth of $\mathrm{M}$ is due to subaerial erosion during the Messinian dessication of the Mediterranean.

The transparent unit substantially smooths irregularities on top of reflector $\mathrm{M}$, thus allowing the upper most stratified unit to be deposited on a much more regular and low relief surface. The minimum post-M sediment thickness $(<135 \mathrm{~ms})$ is also found at Mallorca Collado, extending to the south as a narrow fringe intruded by a volcanic pinnacle east of Ibiza (Fig. 8B). A similar situation is observed on profile A (Fig. 5). Northwest and, especially, southeast of Mallorca Collado, post-M sediment thickens rapidly downslope and towards the large depression to the southeast, with local maximum of $>540 \mathrm{~ms}$. The sediment distribution into this depression is uneven with marked thickenings and thinning in short intervals. As an example, the crest of one of the Horizon M highs is capped by less than $90 \mathrm{~ms}$ of sediment, while the crests of two other M surface highs are covered by less than $270 \mathrm{~ms}$.

\section{Seafloor relief-forming processes}

Three interrelated processes appear to be responsible for the sea floor morphology of the study area. These are normal faulting, sediment instability and gas expulsion (cf. Sections 3 and 4). Both swath bathymetry data and high-resolution seismic reflection profiles indicate that the three processes have probably been active in recent times.

Since the Balearic Promontory is the northeast continuation of the Betic Ranges in the Iberian Penninsula, which are tectonically active, some seismicity could be expected in the Mallorca Channel. The most seismically active area in the Baleares is Sierra Norte in the island of Mallorca. The Mallorca Channel lies along a line connecting the northeast-southwest oriented Sierra Norte in Mallorca to the Island of Ibiza. As a result some seismicity could be anticipated at the
Mallorca Channel. Regional seismologic digital data has only been recorded since 1986 (Centro Nacional de Información Sísmica, Instituto Geográfico Nacional, http://www.geo.ign.es). Older, pre-digital recording does not allow precise epicenter/hypocenter location to determine whether they are associated with tectonic features in the Mallorca Channel. Since 1986 one event of magnitude 3.0 has been reported in the Mallorca Channel. Three additional events have occurred in the Central Rift in the island of Mallorca (Fig. 9).

Seismic events are much more abundant west of Ibiza, both onshore and offshore, where they are associated with normal and strike-slip faults of the Betic range. The whole Balearic Promontory, including the Mallorca Channel, appears to be less seismically active than the Betic Range in the Alicante area and the Catalan Ranges (Fig. 9). As faults cutting the Plio-Quaternary units in the Mallorca Channel offset soft sediments, earthquake triggering behaviour is unlikely. Therefore, seismicity can only be a secondorder factor as far as sediment instability and sea floor relief formation are concerned.

If seismicity is not the prime cause of the deformation, it is possible that deformation of the upper stratified unit in the Mallorca Channel may possibly be related to the nature of the underlying units, the latest Messinian-early Pliocene acoustic transparent unit. However, such flow may involve the Upper Messinian Evaporites above Horizon M.

Down dip gravitational sliding of the Plio-Quaternary strata occurred along the top of the transparent, or the Upper evaporite unit. The mud Plio-Quaternary unit may have relatively high water content that would favor gravitational sliding of the sediments above it. Such materials could enhance the downslope displacement of the sediments above then, the water and possibly gas saturated transparent unit and the Upper Evaporites also would account for the diapirs on profile B (Fig. 5).

The rheological property (high water content) for transparent Unit suggest rapid deposition as indicated by ODP, DSDP results and the study by Stanley (1985). Such a rapid sedimentation would not be surprising after the relatively rapid flood that followed the Messinian dessication of the Mediterranean. In addition to the mechanical properties of the transparent layer and the Upper Evaporites, downslope sliding 


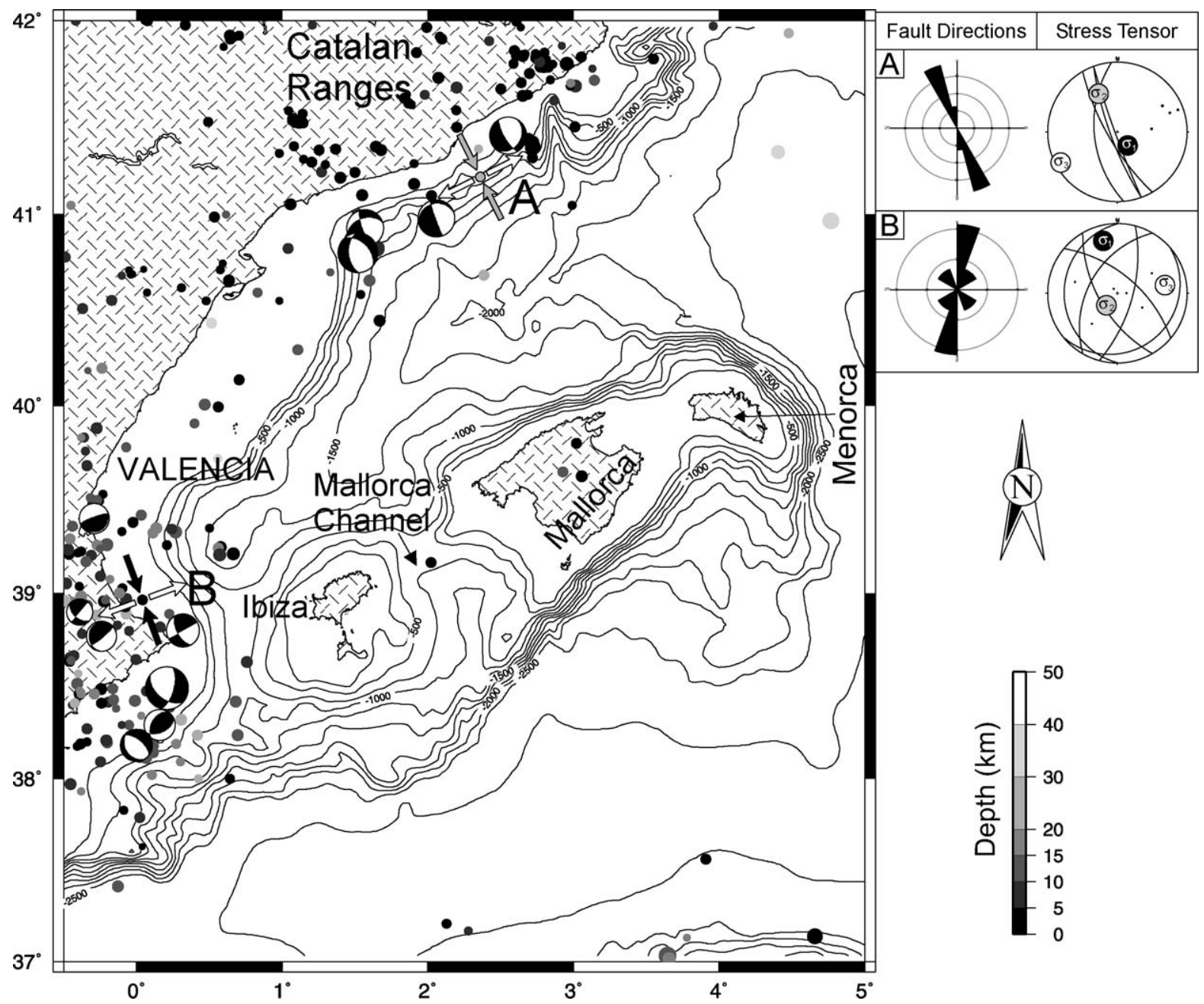

Fig. 9. Distribution of earthquake epicenters in the Balearic Promonotory and nearby areas in mainland Spain from 1986 to 2000 . Compiled from Instituto Geográfico Nacional seismic digital data base, http://www.geo.ign.es). Only four events of a magnitude $>0$ are recorder in the Balearic Promontory east of Ibiza. One of them is located on Mallorca Channel. Focal Mechanisms are from Herraiz et al. (2000). Stresses were calculated following Reches et al. (1992) procedure. Depth contours from Smith and Sandwell (1997).

could be favored by the overall seaward tilting of the M surface, itself enhanced by differential subsidence of the Mallorca Channel along its margins.

As the overlying sediments slid seaward, they broke up locally into series of blocks that experienced some degree of rotation while being transported downslope, thus leading to the formation of the seafloor undulating topography observed in various places (Figs. 3 and 7, profile A). Sliding also may have triggered the injection of materials from the transparent unit along the fault planes separating the blocks, thus reinforcing instability through a sort of feedback mechanism. The configuration of the upper Plio-Quaternary sequence tends to mimic the geometry of Horizon M below the Upper Evaporites. Initially, this is due to sediment draping, but it also suggests that the residual topography of Horizon M influenced the deformation of the transparent unit above it. This deformation in turn propagated upwards into the stratified Plio-Quaternary unit. If so, the listric fault pattern displayed by the Plio-Quaternary unit may be due not simply to down slope motion, but to a 
control by the inherited topography of Horizon $\mathrm{M}$ as demonstrated by the model studies of Gaullier et al. (1993). The mechanical properties of the transparent unit, which is an addition factor that favored the downward/upward offsets in the stratified unit, could also account for the lack of faults in the transparent unit itself.

Gliding and associated deformation over a soft unit also would explain most of the shallow tectonic fabric and seafloor relief in the Mallorca Channel. Such a mechanism is known from the Gulf of Mexico (Cobbold and Szatmari, 1991; Montgomery and Moore, 1997), off Angola (Burollet, 1975; Duval et al., 1992; Spathopoulos, 1996), off Brazil (Cobbold and Szatmari, 1991; Demercian et al., 1993) and in the Eastern Mediterranean (Gaullier et al., 2001). However, deformation in the Mallorca Channel and surroundings, if resulting from gliding over a décollement layer, is not as pronounced as reported elsewhere. Gliding over evaporites off West Africa, for example, has mobilized the evaporites below the gliding surface into rollers and diapirs, and the sediments above these evaporites into turtlebacks and rafts where blocks become separated from one another with salt diapirs intruding into the space between them (Spathopoulos, 1996). The gliding sediments themselves are severely folded at the toe of the salt basin. The absence of such deformation levels in the Mallorca Channel area may be due to the limited thickness of sediment involved and to the relatively shallow water depth of the study area which reduces the gliding run.

\section{Conclusions}

The present-day seafloor morphology of the Mallorca Channel has been shaped by a network of normal faults cut into the Plio-Quaternary sediments and by fluid escape processes. The fault network may have resulted from downslope gliding over a deformable water saturated layer of latest Messinian-early Pliocene age and may involve the Messinian Upper Evaporites. Gliding could have been further favored by the seaward dip of the Messinian erosional surface and tilting of the Plio-Quaternary and older strata because of differential subsidence. Faults in the insular slopes have played a major role in the creation of the overall physiography of the study area. While gliding downslope, the upper Plio-Quaternary sediments became detached by gravitational process over the latest Messinian-Pliocene incompetent muds and the Messinian Upper Evaporites to form structures ranging from creep folds to slumps and slides, some of which triggered debris flows.

Large pockmarks are one of the most noticeable features on the seafloor of the Mallorca Channel. The relation of the pockmarks observed in the shaded relief images of the Mallorca Channel (Figs. 2 and 3 ) and the faults described is unclear at this stage. We cannot exclude that they are unrelated to the main faults. The relatively large size of the pockmarks suggests that they cannot result from biogenic gas expulsion. They are most likely formed by the expulsion of thermogenic gas somehow associated to the volcanic field in between Mallorca and Ibiza islands and northward to the Valencia Trough.

The observed geomorphic instability in the Mallorca Channel and surroundings may have significant economic and social impacts. Services in the Balearic Islands largely rely on an extensive network of communication and electrical submarine cables connecting the islands to Spain's mainland and in between themselves. This network is going to be extended in near future through the lying of a gas pipeline from Valencia to Ibiza and to Mallorca that will cross the Mallorca Channel. This will represent a huge investment which is critical to the islands' environmental future. The gas that will flow through the pipe is aimed at generating cleaner energy than at present. Therefore the seafloor instabilities described above must be further studied and monitored because of their potential to disrupt this network. A throughout understanding of the seafloor morphology and the causative processes appears essential to ensure future welfare of the Baleares, with Mallorca ahead.

\section{Acknowledgements}

We express our appreciation to the Captain and crew of B.I.O. Hespérides and to the scientific party of the ZEE cruises to the Balearic Promontory. We also thank J. Molinero, for his computer support and R. Gómez and M.A. Bécares from Instituto Español de Oceanografia for their technical assistance during and after the cruises. R. Capote reviewed an early 
version of the paper and provided useful suggestions. We wish to thank the reviewers D.G. Masson, M.G. Green and D.J.W. Piper for their constructive comments that were most helpful in improving the manuscript. This research was funded through the Spanish ZEE Program. GRC Marine Geosciences of the University of Barcelona is funded by Generalitat de Catalunya.

\section{References}

Acosta, J., Muñoz, A., Herranz, P., Palomo, C., Ballesteros, M., Vaquero, M., Uchupi, E., 2001a. Geodynamics of the Emile Baudot escarpment and the Balearic Promontory, western Mediterranean. Mar. Pet. Geol. 18 (3), 349-369.

Acosta, J., Muñoz, A., Herranz, P., Palomo, C., Ballesteros, M., Vaquero, M., Uchupi, E., 2001b. Pockmarks in the Ibiza Channel and western end of the Balearic Promontory (western Mediterránean) revealed by multibeam mapping. Geo-Mar. Lett. 21, $123-130$.

Alonso, B., Guillen, J., Canals, M., Serra, J., Acosta, J., Herranz, P., Sanz, J.L., Catafau, E., 1988. Los sedimentos de la plataforma continental balear. Acta Geol. Hisp. 23, 185-196.

Ballesteros, M., 2000. Estudio morfológico y estructural basado en datos geofísicos del area submarina situada al E de las Islas Pityusas (Mar Balear). Tesis de Licenciatura, Facultad de CC. Geológicas. Universidad Complutense, Madrid. 162 pp.

Burollet, P.F., 1975. Tectonique en radeaux en Angola. Bull. Soc. Geol. Fr. 17, 503-504.

Canals, M., Serra, J., 1989. Sedimentation and main Plio-Quaternary seismic features in the Balearic margin. Eur.Geophys. Soc. Ann. Sp. number, p. 14.

Canals, M., Serra, J., Riba, O., 1982. Toponimia de la Mar Catalano-Balear (con un glosario de términos genéricos). Boll. Soc. Hist. Nat. Balears 26, 169-194.

Cobbold, P.R., Szatmari, P., 1991. Radial gravitational gliding on passive margins. Tectonophysics 188, 249-289.

Coleman, D.F., Ballard, R.D., 2001. A highly concentrated region of hydrocarbon seeps in the southeastern Mediterranean. GeoMar. Lett. 21, $162-167$.

Comas, M.C., Zahn, R., Klaus, A., et al., 1996. Proc. Ocean Drill. Program, Initial Rep., vol. 161. Ocean Drilling Program, College Station, TX.

Cramp, A., O’Sullivan, G., 1999. Neogene sapropels in the Mediterranean: a review. Mar. Geol. 53 (1-4), 11-28.

Demercian, S., Szatmari, P., Cobbold, P.R., 1993. Style and pattern of salt diapirs due to thin-skinned gravitational gliding, Campos and Santos basins offshore Brazil. Tectonophysics 228, 393-433.

Duval, B., Cramez, C., Jackson, M.P., 1992. Raft tectonics in the Kwanza Basin, Angola. Mar. Pet. Geol. 9, 389-404.

Gaullier, V., Brun, J.P., Guérin, G., Ledcanu, H., 1993. Raft tectonics: the effect of residual topography below a salt décollement. Tectonophysics 228, 363-381.
Gaullier, V., Loncke, L., Mascle, J., Bellaiche, G., Vendeville, B., Courp, T., Moreau, A., Radan, S., Sardou, O., 2001. Combined thin-skinned and thick-skinned tectonics in the eastern nile deep-sea fan, Eastern Mediterranean: results from the recent "FANIL" survey. Abstracts, European Union of Geosciences XI, 517.

Herraiz, M., De Vicente, G., Lindo, R., Giner, J., Simón, J.L., González-Casado, J.M., Vadillo, O., Rodríguez, M.A., Givuendez, J.I., Casas, A., Cabañas, L., Rincón, P., Cortes, A.L., Ramirez, M., Lucini, M., 2000. The recent (upper Miocene to Quaternary) and present tectonic stress distribution in the Iberian peninsula. Tectonics $19,762-786$.

Hsü, K.J., Montadert, L., Bernouilli, D., Cita, M.B., Erickson, A., Garrison, R.E., Kidd, R.B., Melieres, F., Muller, C., Wright, R., 1977. History of the Mediterranean salinity crises. Nature 267, $399-403$.

IEO-IHM., 1999a. Zona Económica Exclusiva, Hoja M 14. Mapa Batimétrico. Edit. Ministerio Agricultura, Pesca y Alimentación 1999. Instituto Español de Oceanografía. Departamento de Geología y Geofísica Marina (Madrid).

IEO-IHM., 1999b. Zona Económica Exclusiva, Hoja M 13. Mapa Batimétrico. Edit. Ministerio Agricultura, Pesca y Alimentación 1999. Instituto Español de Oceanografía. Departamento de Geología y Geofísica Marina (Madrid).

Instituto Geográfico Nacional. Centro Nacional de Información Sísmica. (http://www.geo.ign.es/).

Limonov, A.F., Woodside, J.M., Cita, M.B., Ivanov, M.K., 1996. The Mediterranean ridge and related mud diapirism; a background. Mar. Geol. 132, 7-19.

Maldonado, A., Canals, M., 1982. El margen continental surBalear: Un Modelo deposicional reciente sobre un margen de tipo pasivo. Acta Geol. Hisp. 17, 241-254.

Maldonado, A., Nelson, H., 1990. The Ebro margin study, northwestern Mediterránean sea; an introduction. Mar. Geol. 95 (3-4), 157-163.

Montadert, L., Letouzey, J., Mauffret, A., 1978. Messinian event: seismic evidence. In: Hsü, K., Montadert, L., et al. (Eds.), Initial Reports of the Deep Sea Drilling Project, vol. 42, Part 1. U.S. Government Printing Office, Washington, D.C, pp. $1037-1050$.

Montgomery, S.L., Moore, D.C., 1997. Subsalt play, Gulf of Mexico: a review. Am. Assoc. Pet. Geol. Bull. 81, 871-896.

Muñoz, A., Acosta, J., Palomo, C., Herranz, P., Sanz, J.L., Molinero, J., Gómez, R., Bécares, M.A., Uchupi, E., 1998a. Datos batimétricos y sísmicos en el ámbito de la investigación de la Zona Económica Exclusiva Española. I Asamblea HispanoPortuguesa de Geodesia y Geofísica. Almeria, Spain. 11 pp.

Muñoz, A., Palomo, C., Acosta, J., Pardo de Domlebum, M., 1998b. Hydrographic and oceanographic programme for the spanish EEZ. EEZ Technol. 2, 71-75.

Olivera, C., Susagna, T., Roca, A., Goula, X., 1992. Seismicity of the Valencia trough and surrounding areas. Tectonophysics 203 (1-4), 99-109.

Panizza, M., 1996. Environmental geomorphology. Developments in Earth Surface Processes, vol. 4. Elsevier, The Netherlands. $268 \mathrm{pp}$.

Pardo de Domlebum, M., Acosta, J., Rico, J., Herranz, P., 1998. 
Oceanographic and Hydrographic Investigation Plan of the Spanish Economic Exclusive Zone (ZEEE). IV ${ }^{\circ}$. Environmental and Engineering Geophysics Congress, Barcelona, Spain.

Reches, Z., Baer, G., Haztor, Y., 1992. Constraints on the strength of the upper crust from stress inversion of fault slip data. J. Geophys. Res. 97, 1281-1293.

Riding, R., Braga, J.C., Martín, J.M., Sánchez-Almazo, S.M., 1998. Mediterranean Messinian salinity crisis: constraints from coeval marginal basins: Sorbas, southeastern Spain. Mar. Geol. $146,1-20$.

Ryan, W.B.F., Hsü, K.J., et al., 1973. Hellenic trench sites 127 and 128. In: Ryan, W.B.F., Hsü, K.J., et al. (Eds.), Initial Rep. DSDP, vol. 13 (Pt. 2). U.S. Gov. Printing Office, Washington, pp. $243-322$.

Sabat, F., Roca, E., Muñoz, J.A., Vergés, J., Santanach, P., Sans, M., Masana, E., Estévez, A., Santistan, C., 1995. Role of extension and compression in the evolution of the eastern margin of Iberia: the ESCI-Valencia Trough seismic profile. Rev. Soc. Geol. Esp. $8,431-448$.

Smith, W.H.F., Sandwell, D.T., 1997. Global seafloor topography from satellite altimetry and ship depth soundings. Science 277, $1956-1962$.

Spathopoulos, F., 1996. An insight on salt tectonics in the Angola Basin, South Atlantic. In: Alsop, G.I., Blundell, D.J., Davison, I. (Eds.), Salt Tectonics. Spec. Paper-Geological Society, vol. 100, pp. $153-174$.

Stanley, D.J., 1985. Mud redeposition processes as a major influence on Mediterranean margin-basin sedimentation. In: Stanley, D.J., Wezel, F.C. (Eds.), Geological Evolution of the Mediterranean basin. Springer-Verlag, New York, pp. 377-410.

Vidal, N., Gallart, J., Dañobeitia, J.J., 1998. A deep seismic crustal transect from the NE Iberian Peninsula to the western Mediterranean. J. Geophys. Res. 103, 12381-12396. 